\title{
Calcium Chloride Applications to Improve Fruit Quality on Bruised and Diseases of Pineapple (Ananas comosus (L) Merr)
}

\author{
Nungki Kusuma Astuti ${ }^{1}$, Moch. Dawam Maghfoer ${ }^{2}$, and Roedy Soelistyono ${ }^{2}$ \\ ${ }^{I}$ Graduate School of Plant Science, Faculty of Agriculture, Brawijaya University, Jl.Veteran Malang 65145, \\ East Java, Indonesia. \\ ${ }^{2}$ Faculty of Agriculture, Brawijaya University, Jl.Veteran Malang 65145, East Java, Indonesia.
}

\begin{abstract}
The problems faced by producer canned of pineapple are the high of bruised which caused by the mechanical damage such as pressure, vibration during harvest, transport to the fruit processing and pathological damage caused by fruit diseases. The objective of research was to obtain the treatment time of $\mathrm{CaCl}_{2}$ applications and dosage of $\mathrm{CaCl}_{2}$ to improve the fruit quality of pineapple. This research used Split Plot Design and each treatment replicated 3 times. The main plot is time of $\mathrm{CaCl}_{2}$ applications that consists of three levels, thats are : 90 day after forcing (daf) (W90), 120 daf (W120) and twice time of $\mathrm{CaCl}_{2}$ applications on 90 and $120 \mathrm{daf}(\mathrm{W} 90+120)$. The sub plot is dosage of $\mathrm{CaCl}_{2}$ that consists of three levels, thats are : $50 \mathrm{~kg} \mathrm{ha} \mathrm{H}^{-1}$ (C50), $75 \mathrm{~kg} \mathrm{ha}^{-1}$ (C75) and $100 \mathrm{~kg} \mathrm{ha}^{-1}$ (C100). The results of research showed that the combined treatment twice time of $\mathrm{CaCl}_{2}$ applications on 90 and 120 day after forcing and dosage of $\mathrm{CaCl}_{2} 100 \mathrm{~kg} \mathrm{ha}^{-1}$ produces the calcium content on fruit is higher than the other combined treatments and produce the fruit texture, percentage of fruit diseases and percentage of bruised are lower than the other combined treatments.
\end{abstract}

Keywords : Calcium chloride, pineapple

\section{Introduction}

Pineapple is now the third most important tropical fruit in world production after banana and citrus. The processing of pineapple has made the fruit well known through out the temperate developed world. International trade is dominated by a few multinational companies that have developed the infrastructure to process and market pineapple. Indonesia ranks third from producing canned and fresh fruit of pineapple in the world after Thailand and Philippines. Pineapple canned being developed business priorities in Indonesia (Iskandar and Soelaeman, 2007; Loeillet, 1997).

Pineapple plants divided into 4 variety, namely Smooth Cayenne, Queen, Spanish and Abacaxi. Variety of pineapple are widely grown in Indonesia is Smooth Cayenne and Queen. Smooth Cayenne known to be more sensitive to pests (fruit borers, mites, symphilid, nematodes) and diseases (mealybug wilt, fusarium rot, heart rot on fruit, rotten base) but are also more tolerant of Phytoptora sp. and resistant to fruit fall caused by Erwinia chrysanthemi. The fruit diseases that often attack in pineapple are brown spot, cork spot, marbling and pink diseases (Rohrbach et al., 2003; Petty et al., 2002).

A wide diversity of machines have been developed to assist in the harvesting of pineapples. The problems faced by producer canned of pineapple are the high of bruised which caused by the mechanical damage such as pressure, vibration during harvest, transport to the fruit processing and pathological damage caused by fruit diseases. To overcome this problem need to improve the fruit quality of pineapple with calcium chloride application. Calcium has been known to be effective in maintaining the hardness of fruit texture. One part of the fruit cell is middle lamella, an area which contains pectin that when interacting with $\mathrm{Ca}^{2+}$ will form $\mathrm{Ca}$ pectat, which a role in adding to the attachment between cells. The hard fruit texture will make the microorganisms that cause fruit disease difficult to infection (Mishra, 2002).

The objective of research was to determine the effect of calcium chloride application to improve fruit quality on bruised and diseases of pineapple.

\section{Material And Method}

The research conducted on January till April 2013 at Lampung Indonesia. This research used Split Plot Design and each treatment replicated 3 times. The main plot is time of $\mathrm{CaCl}_{2}$ application that consists of three levels, thats are : 90 day after forcing (daf), 120 daf and twice time of $\mathrm{CaCl}_{2}$ applications on 90 and 120 daf. The sub plot is dosage of $\mathrm{CaCl}_{2}$ that consists of three levels, thats are : $50 \mathrm{~kg} \mathrm{ha}^{-1}, 75 \mathrm{~kg} \mathrm{ha}^{-1}$ and $100 \mathrm{~kg} \mathrm{ha}^{-1}$. The observation is given through destructive, include : calcium content, fruit texture, percentage of fruit bruised and percentage of fruit diseases. 
Analysis of data using the analysis of variance $\mathrm{F}$ test at $5 \%$ significance level. If there are significant different will be followed by Least Significant Difference Test (LSD) at 5\% level. Comparison between treatments and control using analysis orthogonal contrasts.

\subsection{Calcium content}

\section{Results And Discussion}

Calcium content is effected by interaction of treatment time and dosage $\mathrm{CaCl}_{2}$ application. The combined treatment twice time of $\mathrm{CaCl}_{2}$ applications on 90 and 120 daf with dosage of $\mathrm{CaCl}_{2} 50 \mathrm{~kg} \mathrm{ha}^{-1}$ showed that not significant different with the combined treatment twice time of $\mathrm{CaCl}_{2}$ applications on 90 and 120 daf with dosage of $\mathrm{CaCl}_{2} 75 \mathrm{~kg} \mathrm{ha}^{-1}$ and combined treatment twice time of $\mathrm{CaCl}_{2}$ applications on 90 and $120 \mathrm{daf}$ with dosage of $\mathrm{CaCl}_{2} 100 \mathrm{~kg} \mathrm{ha}^{-1}$. Both of combined treatment produce the percentage of fruit bruised higher than the other combined treatment (Table 1). Comparison treatments and control showed that the treatment $\mathrm{CaCl}_{2}$ application produce the calcium content significant different and higher than the control (Table 2).

Tabel 1. Calcium content (mg. ${ }^{-1}$ ) which effected by interaction the treatment time of $\mathrm{CaCl}_{2}$ application and

\begin{tabular}{cccc}
\multicolumn{4}{c}{ dosage of $\mathrm{CaCl}_{2}$. } \\
\hline Time of $\mathrm{CaCl}_{2}$ application & \multicolumn{3}{c}{ Dosage of $\mathrm{CaCl}_{2}\left(\mathrm{~kg} \mathrm{ha}^{-1}\right)$} \\
\cline { 2 - 4 }$(\mathrm{daf})$ & 50 & 75 & 100 \\
\hline 90 & $55,88 \mathrm{a}$ & $56,68 \mathrm{ab}$ & $57,50 \mathrm{ab}$ \\
$90+120$ & $59,37 \mathrm{bcd}$ & $60,75 \mathrm{~cd}$ & $61,67 \mathrm{~d}$ \\
120 & $55,45 \mathrm{a}$ & $57,42 \mathrm{ab}$ & $58,35 \mathrm{abc}$ \\
\hline LSD 5\% & & 3,21 & \\
\hline
\end{tabular}

Values followed by the same letter showed that not significant different by Least Significant Difference Test (LSD) at 5\% level, daf : day after forcing.

Tabel 2. Comparison calcium content between treatment $\mathrm{CaCl}_{2}$ application and control.

\begin{tabular}{cc}
\hline Treatment & Calcium content $\left(\mathrm{mg} . \mathrm{l}^{-1}\right)$ \\
\hline Control & $50,40 \mathrm{a}$ \\
Treatment & $58,12 \mathrm{~b}$ \\
\hline
\end{tabular}

Values followed different letter showed that significant different by analysis of orthogonal contras.

Calcium is one of the chemicals that role an important in maintaining the fruit quality to the membrane and cell wall structure. One part of the cell wall of the middle lamella, an area that contains a lot of pectin compound and when interacting with $\mathrm{Ca}^{2+}$ to form $\mathrm{Ca}$ pektat which then act to add attachments between cells. The availability of different calcium in each fruit will produce the different calcium content on fruit (Garcia $e t$ al., 1995; Mishra, 2002).

\subsection{Fruit texture}

Fruit texture is effected by interaction of treatment time and dosage $\mathrm{CaCl}_{2}$ application. The combined treatment twice time of $\mathrm{CaCl}_{2}$ applications on 90 and 120 daf with dosage of $\mathrm{CaCl}_{2} 100 \mathrm{~kg} \mathrm{ha}^{-1}$ produce the fruit texture higher than the other combined treatment (Table 3). Comparison treatments and control showed that the treatment $\mathrm{CaCl}_{2}$ application produce the fruit texture significant different and higher than the control (Table 4).

Tabel 3. Fruit texture $\left(\mathrm{mm} \cdot 10 \mathrm{~g}^{-1} \cdot 10 \mathrm{~s}^{-1}\right)$ which effected by interaction the treatment time of $\mathrm{CaCl}_{2}$ application and dosage of $\mathrm{CaCl}_{2}$.

\begin{tabular}{cccc}
\hline Time of $\mathrm{CaCl}_{2}$ application (daf) & \multicolumn{3}{c}{ Dosage of $\mathrm{CaCl}_{2}\left(\mathrm{~kg} \mathrm{ha}^{-1}\right)$} \\
\cline { 2 - 4 } & 50 & 75 & 100 \\
\hline 90 & $208,89 \mathrm{a}$ & $209,44 \mathrm{a}$ & $235,00 \mathrm{~cd}$ \\
$90+120$ & $238,89 \mathrm{~d}$ & $246,11 \mathrm{e}$ & $260,00 \mathrm{f}$ \\
120 & $212,78 \mathrm{ab}$ & $218,33 \mathrm{~b}$ & $231,67 \mathrm{c}$ \\
\hline LSD 5\% & & 5,78 & \\
\hline
\end{tabular}

Values followed by the same letter showed that not significant different by Least Significant Difference Test (LSD) at $5 \%$ level, daf : day after forcing. 
Tabel 4. Comparison fruit texture between treatment $\mathrm{CaCl}_{2}$ application and control.

\begin{tabular}{cc}
\hline Treatment & Fruit texture $\left(\mathrm{mm} \cdot 10 \mathrm{~g}^{-1} \cdot 10 \mathrm{~s}^{-1}\right)$ \\
\hline Control & $201,78 \mathrm{a}$ \\
Treatment & $229,01 \mathrm{~b}$ \\
\hline
\end{tabular}

Values followed different letter showed that significant different by analysis of orthogonal contras

Fruit texture is an indicator of fruit hardness. Calcium chloride application on fruit will affect the fruit texture due to the interaction of calcium with the cell membrane or cell wall which in this case is pectin. Calcium chloride applications known to retain the fruit texture because calcium chloride solution into the pores of fruit and will work on the bridge galacturonat cell wall on pectin so can make fruit texture is hardness (Abbott and Harker, 2003; Mishra, 2002).

The results of correlation analysis showed that the calcium content was positively correlated with the fruits texture $(\mathrm{R}=0.887$ ), it shows that the higher calcium content can increasing the fruit texture. Relationship between calcium content and fruit texture with the linear regression equation $Y=7,962 x-233,7$ and $R^{2}=0,896$ (Fig. 1a), which means that each additional calcium content $1 \mathrm{mg} \cdot \mathrm{l}^{-1}$ can increasing the fruit texture 7,962 mm. $10 \mathrm{~g}^{-1} \cdot 10 \mathrm{~s}^{-1}$.
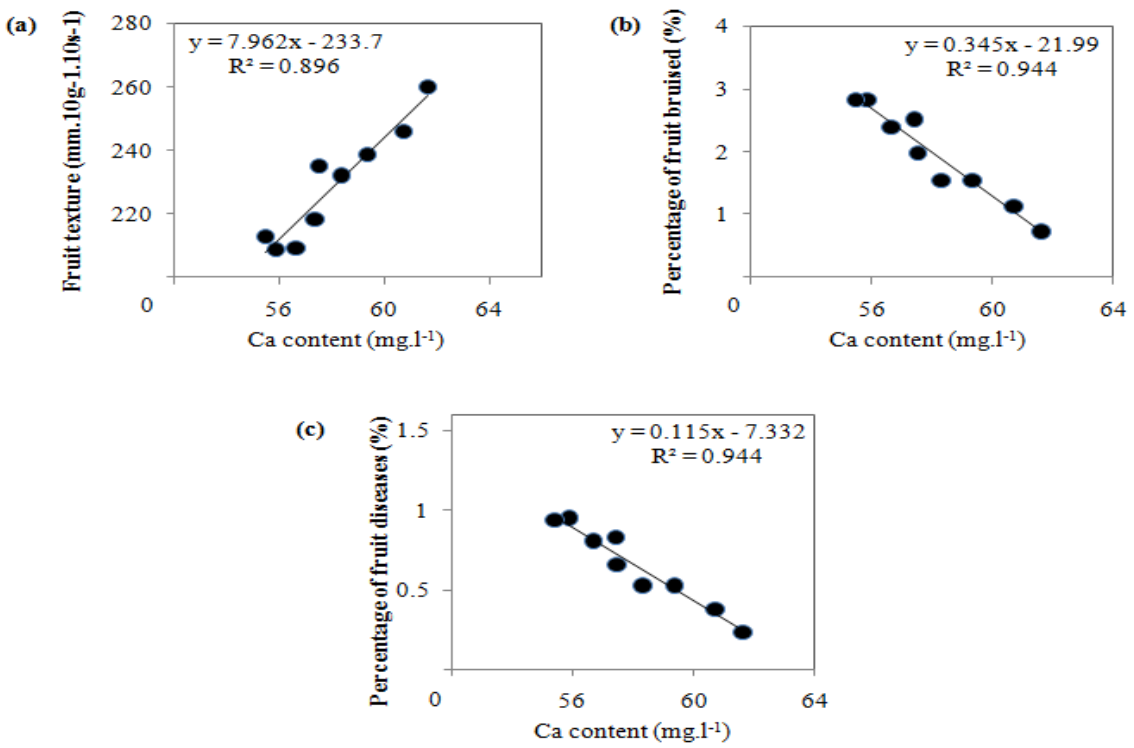

Fig. 1 Relationship between calcium content with (a) fruit texture, (b) percentage of fruit bruised and (c) percentage or fruit diseases.

\subsection{Percentage of fruit bruised}

Percentage of fruit bruised is effected by interaction of treatment time and dosage $\mathrm{CaCl}_{2}$ application. The combined treatment twice time of $\mathrm{CaCl}_{2}$ applications on 90 and 120 daf with dosage of $\mathrm{CaCl}_{2} 50 \mathrm{~kg} \mathrm{ha}^{-1}$ showed that not significant different with the combined treatment twice time of $\mathrm{CaCl}_{2}$ applications on 90 and 120 daf with dosage of $\mathrm{CaCl}_{2} 75 \mathrm{~kg} \mathrm{ha}^{-1}$ and combined treatment twice time of $\mathrm{CaCl}_{2}$ applications on 90 and 120 daf with dosage of $\mathrm{CaCl}_{2} 100 \mathrm{~kg} \mathrm{ha}^{-1}$. Both of combined treatment produce the percentage of fruit bruised lower than the other combined treatment (Table 5). Comparison treatments and control showed that the treatment $\mathrm{CaCl}_{2}$ application produce the percentage of fruit bruised significant different and lower than control (Table 6). 
Tabel 5. Percentage of fruit bruised (\%) which effected by interaction the treatment time of $\mathrm{CaCl}_{2}$ application and dosage of $\mathrm{CaCl}_{2}$.

\begin{tabular}{cccc}
\hline Time of $\mathrm{CaCl}_{2}$ application & \multicolumn{3}{c}{ Dosage of $\mathrm{CaCl}_{2}\left(\mathrm{~kg} \mathrm{ha}^{-1}\right)$} \\
\cline { 2 - 4 } (daf) & 50 & 75 & 100 \\
90 & $2,83 \mathrm{e}$ & $2,40 \mathrm{~cd}$ & $1,97 \mathrm{bcd}$ \\
$90+120$ & $1,55 \mathrm{abc}$ & $1,13 \mathrm{ab}$ & $0,71 \mathrm{a}$ \\
120 & $2,82 \mathrm{de}$ & $2,49 \mathrm{de}$ & $1,55 \mathrm{abc}$ \\
\hline LSD 5\% & & 0,85 & \\
\hline
\end{tabular}

Values followed by the same letter showed that not significant different by Least Significant Difference Test (LSD) at 5\% level, daf : day after forcing.

Tabel 6. Comparison percentage of fruit bruised between treatment $\mathrm{CaCl}_{2}$ application and control.

\begin{tabular}{cc}
\hline Treatment & Percentage of fruit bruised \\
\hline Control & $6,47 \mathrm{~b}$ \\
Treatment & $1,94 \mathrm{a}$ \\
\hline
\end{tabular}

Values followed different letter showed that significant different by analysis of orthogonal contras.

Calcium chloride application on preharvest and postharvest have been done to prevent mechanical and physiological damage on fruit. Calcium will maintain cell walls and always in the form of $\mathrm{Ca}^{2+}$ to prevents damage. The hard of ion calcium caused by the formation cross between the divalent ion calcium with polymer pectin compound on carbonyl cluster galakturonat acid. When ties occur crosswise in large quantities, there will be a wide molecular tissue and reduce the solubility of the compound fruit pectin so sturdy from mechanical influences. (Garcia et al., 1995; Mardini, 2007)

The results of correlation analysis showed that the calcium content was negatively correlated with the percentage of fruit bruised $(\mathrm{R}=-0,943)$, it shows that the higher calcium content can decreasing the percentage of fruit bruised. Relationship between calcium content and percentage of fruit bruised with the linear regression equation $Y=0,345 x-21,99$ and $R^{2}=0,944$ (Fig. 1b), which means that each additional calcium content 1 mg..$^{-1}$ can decreasing decreasing the percentage of fruit bruised $0,345 \%$.

\subsection{Percentage of fruit diseases}

Fruit disease found in this research is a brown spot. Brown spot is a disease of pineapple caused by Penicillium funiculosum and Fusarium moniliforme. Brown spot disease infection occurs during the development and opening of the flower. Pathogen into the plant tissue through natural openings or wounds caused by mites. Symptoms of the disease is characterized by changes apot brown flesh became gray and the center as water soaked (Broadley, 1993; Leal and d'Eeckenbrugge, 2003).

Percentage of fruit diseases is effected by interaction of treatment time and dosage $\mathrm{CaCl}_{2}$ application. The combined treatment twice time of $\mathrm{CaCl}_{2}$ applications on 90 and 120 daf with dosage of $\mathrm{CaCl}_{2} 100 \mathrm{~kg} \mathrm{ha}^{-1}$ produce the percentage of fruit diseases lower than the other combined treatment (Table 7). Comparison treatments and control showed that the treatment $\mathrm{CaCl}_{2}$ application produce the percentage of fruit diseases significant different and lower than the control (Table 8).

Tabel 3. Percentage of fruit diseases (\%) which effected by interaction the treatment time of $\mathrm{CaCl}_{2}$ application and dosage of $\mathrm{CaCl}_{2}$.

\begin{tabular}{cccc}
\hline Time of $\mathrm{CaCl}_{2}$ application & \multicolumn{3}{c}{ Dosage of $\mathrm{CaCl}_{2}\left(\mathrm{~kg} \mathrm{ha}^{-1}\right)$} \\
\cline { 2 - 4 } (daf) & 50 & $75 \mathrm{c}$ & 100 \\
\hline 90 & $4,24 \mathrm{~g}$ & $3,60 \mathrm{de}$ & $\mathrm{cd}$ \\
$90+120$ & $3,08 \mathrm{c}$ & $1,83 \mathrm{~b}$ & $1,27 \mathrm{a}$ \\
120 & $4,11 \mathrm{fg}$ & $3,69 \mathrm{ef}$ & $3,22 \mathrm{cde}$ \\
\hline LSD 5\% & \multicolumn{3}{c}{0,50} \\
\hline
\end{tabular}

Values followed by the same letter showed that not significant different by Least Significant Difference Test (LSD) at 5\% level, daf : day after forcing.

Tabel 4. Comparison percentage of fruit diseases between treatment $\mathrm{CaCl}_{2}$ application and control.

\begin{tabular}{cc}
\hline Treatment & Percentage of fruit diseases (\%) \\
\hline Control & $6,45 \mathrm{~b}$ \\
Treatment & $3,13 \mathrm{a}$ \\
\hline
\end{tabular}

Values followed different letter showed that significant different by analysis of orthogonal contras.

Calcium chloride will work on bridging galacturonat cell walls in the fruit pectin so can make the fruit is hard. The hard fruit texture will make the microorganisms that cause fruit rot difficult to infection (Mishra, 
2002). Calcium can maintain the enzyme produced by fungi or bacteria that cause rotting fruit or fruit disease (Huang et al. (2012).

The results of correlation analysis showed that the calcium content was negatively correlated with the percentage of fruit bruised $(R=-0,943)$, it shows that the higher calcium content can decreasing the percentage of fruit bruised. Relationship between calcium content and percentage of fruit bruised with the linear regression equation $\mathrm{Y}=0,345 \mathrm{x}-21,99$ and $\mathrm{R}^{2}=0,944$ (Fig. 1b), which means that each additional calcium content $1 \mathrm{mg} . \mathrm{l}^{-1}$ can decreasing decreasing the percentage of fruit bruised $0,345 \%$.

\section{Conclusion}

The combined treatment twice time of $\mathrm{CaCl}_{2}$ applications on 90 and 120 day after forcing and dosage of $\mathrm{CaCl}_{2}$ $100 \mathrm{~kg} \mathrm{ha}^{-1}$ produces the calcium content on fruit is higher than the other combined treatments and produce the fruit texture, percentage of fruit diseases and percentage of bruised are lower than the other combined treatments.

\section{References}

[1]. Abbott, F.G and F.R. Harker. 2003. Sensory interpretation of instrumental measurements 2: sweet and acid taste of apple fruit. Postharvest biology and technology. 24:241-250.

[2]. Broadley, R.H.; C.W. Rudolph and S.Eric. 1993. Pineapple Pest dan Disorders. Department of Primary Industry. Queensland.

[3]. Garcia, J. M., Ballesteros M. J. dan M. A. Albi. 1995. Effect of Foliar Applications of CaCl $\mathrm{C}_{2}$ on Tomato Stored at Different Temperature. Journal Agriculture Food Chemistry. 43: 9-12.

[4]. Huang, S.; G. Zhu, L. Qin, X. Zhou, F. Huang, Q. Li, W. Yan, H. Huang, Z. Cen, G. Fu, and C. Hu. 2012. Enhancement of Efficacy in Controlling Postharvest Decays and Extending Shelf Life of Mangoes by Combined Pre- and Post- harvest Chemical Aplications, International Journal of Agriculture and Biology.14 (2) : 176-182

[5]. Iskandar, D.E, dan H.T. Soelaeman. 2007. Raja nanas dunia. Swamajalah 46 p. 21-22. 2012.

[6]. Leal, F. and G.C. d'Eeckenbrugge. 2003. The Pineapple, Fruit Breeding,Tree and Tropical Fruits. CABI publishing. New York.

[7]. Loeillet, D. 1997. Panorama du marché mondial de l'ananas: l'importance de l'Europe (The world pineapple market: the importance of Europe). Acta Horticulturae 425, 37-48.

[8]. Mardini, 2007. Sifat Fisik, Kimia dan Sensoris Buah Nenas dengan Penambahan Kalsium Sitrat Malat (CCM) dan Pektin. Skripsi. Universitas Sriwijaya. Palembang.

[9]. Mishra, M. 2002. Lead Acetate Induced Citotoxicity in Male Germinal Cell of Swiss Mice. Swiss. p.291-294.

[10]. Petty, G.J.; S.R. Graham and D.P. Bartholomew. 2002. Tropical Fruit Pest and Pollinators. CABI Publishing. New York.

[11]. Rohrbach, K.G and M.W. Johnson. 2003. The Pineapple, Pest, Disease and Weeds. CABI Publishing. New York. 